\title{
The Mediating Role of Coaching Behavior in The Effects of Intrinsic Motivation on Work Addiction Among Nurses
}

\author{
Nukhet BAYER ${ }^{1}$, İsmet ŞAHIIN ${ }^{2}$
}

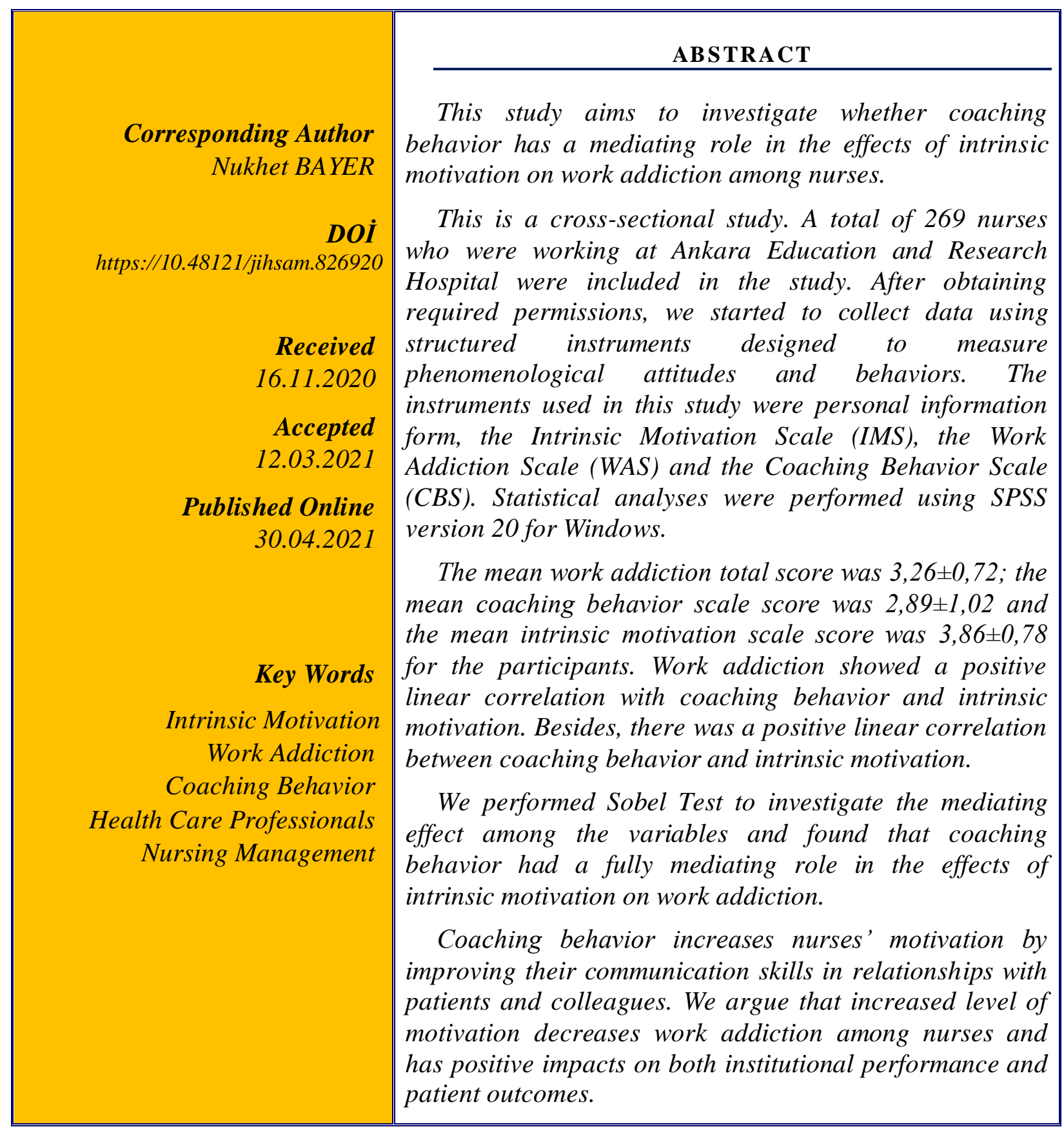

${ }^{1}$ Assistant Professor, Lokman Hekim University, Faculty of Health Sciences, Nursing Depaertment, Ankara, Turkey.nukhetbayer@yahoo.com Orcid:0000-0003-3177-0596

2 Prof. Dr.. Lokman Hekim Universitesi Institute of Health Sciences Ankara, Türkiye. ismet.sahin@lokmanhekim.edu.tr Orcid: 0000-0003-0878-5669 


\section{INTRODUCTION}

There is a rapid change in the health care system and the presentation of health services. Acceleration in innovation, global competition, and diseases that are hard to deal with, make things harder for healthcare professionals. In this regard, it is a necessity to motivate the feelings of curiosity, interest, empathy, and affection among health care professionals, which is like their professions, to improve the quality and efficiency of nursing care holding an important place in health services. It may be argued that personal characteristics and work environment have impacts on work addiction and intrinsic motivation among nurses. To gain a positive development in this impact, employees require to get managerial coaching. Since nurses provide continuing health service, they have some situations such as work-related concerns and difficulty falling asleep after working hours or when they are off-the-clock (Kubota et al., 2010; Shimazu et al., 2010). In health care, workplace environment involves units require maximum attention, such as intensive care, emergency departments, and operating rooms. This situation creates a stressful job environment. Work pressure on nurses, who provide $7 / 24$ healthcare service, causes the repeated checking of the duties done. It has been reported in the literature that nursing is among the professions at the risk of work addiction (Quinones \& Griffiths, 2015).

In health care system, among the intrinsic and extrinsic motivators in the workplace are sufficient resources, supportive management, professional statue, fair distribution of the workload, flexible working hours, occupational health and safety, payments, rewards, job love, satisfying relationships with other health care professionals (Abu Yahya et al., 2019; Buchan, 2010). Managers have important roles in motivating employees. Among a manager's responsibilities are evaluation and accountability, establishing effective working relationships, making learning easier, creating an environment for learning, implementing evidence-based practices, and assessment of learning (Ali, 2008). Managers should guide employees by using coaching behaviors to ensure that they can make better decisions. Besides, they should support health care workers in fulfilling their responsibilities. All of these will increase employee motivation.

Motivation is important for workforce management in health care systems as it is associated with performance levels, human resource management, and patient satisfaction. The inherent desire of individuals to engage in activities for their fundamental needs forms the basis for intrinsic motivation. In other words, people are curious and have a desire to know, to inquire, and to develop since birth (Ryan \& Deci, 2000). There are two types of motivation, intrinsic and extrinsic motivation. Intrinsic motivation is the type of motivation that emerges from the interest in a job and it is related to the nature of the job. Among intrinsic motivators are job autonomy, job involvement, the value of the job for the employee, creativity, responsibility, and use of abilities at work. Intrinsically motivated people to move to action for enjoyment or opportunity about a job or a task rather than external rewards, pressures, or needs (Saracel et al., 2015). A large number of nurses, among other staff is too significant to be ignored. This situation is also important regarding the workload in the sector. Thus, motivation is a key factor for nurses to cope with the difficulties they encounter. It has been showing that a high level of motivation and satisfaction increases employee performance and productivity (Hammoudi et al., 2018). In the health care system, high turnover rates adversely affect access to care and reduce the quality and level of health care service. The shortage of staff leads to a reduction in time spent on patient care. Moreover, the lack of experienced staff undermines teamwork and causes a decrease in individual and organizational performance (Buchan, 2010). Decreases in individual and organizational performance adversely affect quality of health care services, as well as reduce competitiveness of an institution.

Advances in technology, acceleration in innovation, and global competition have increased customer demands and led to changes in expectations. In response to these developments, employees need to update their knowledge and compete with others by establishing social network services. Through the internet and computer-based working, employees can work wherever they are and whenever they want; however, this situation sometimes causes a blurred line between work and private life (van Beek et al., 2012). The people blurring the line between work and private life in this manner are called as workaholics. The term workaholism was first described by Oates as "work addiction, the compulsion or the uncontrollable need to work incessantly" (Bonebright, 2002). Spence and Robins (1992) focus on three characteristics of work addiction. These characteristics are the work involvement, feeling an addictive drive to work under internal pressure and the lack of work enjoyment. It has been suggested that work addiction may be a kind of adaptation for the individuals working at stressful workplaces for a long time, and also it has been revealed that work addiction affects burnout (Homer, 1985; Kanai et al., 1996). Nurses, who are one of the key stakeholders in the health care system, may be more likely to feel burned out. It has become compulsory to determine more effective approaches to establish an educational and supportive environment for health care professionals to improve their skills and knowledge and the quality of care and to develop appropriate policies to achieve this purpose (Manzi et al., 2017). Health institutions utilize the coaching approach as a solution to this compulsory situation. 
Coaching is generally a long term relationship between nurses and nurse managers providing leading support for professional development (Jacobs, 2018). It is assumed that coaching behavior increases job satisfaction among nurses via developing communication skills to improve the relationship between nurses and their colleagues and patients, and the satisfaction increased by coaching affects patient satisfaction.

\section{METHOD}

\section{Purpose and Hypotheses}

This study aims to investigate the mediating role of coaching behavior in the effects of intrinsic motivation on work addiction.

H1: Intrinsic motivation affects work addiction positively.

$\mathrm{H} 2$ : Coaching behavior affects work addiction positively.

H3: Coaching behavior affects intrinsic motivation positively.

H4: The variable coaching behavior has a mediating role in the effects of intrinsic motivation on work addiction.

\section{Population and Sample}

The population of this study consisted of nurses who were working at an education and research hospital in Ankara. Convenience sampling, a type of non-probability sampling technique, was used in the study 17 . The study sample was composed of 300 nurses who volunteered to participate in the study after informed about the study. The questionnaires used to collect the data were distributed to nurses who were present at the hospital and volunteered to participate in the study between August and September 2019. We removed the questionnaires with missing data, so the data were collected from a total of 269 nurses.

\section{Instruments}

The data were collected using sociodemographic information form developed by researchers to determine phenomenological (personal and professional) characteristics of nurses, the Dutch Work Addiction Scale (DUWAS), Intrinsic Motivation Scale, and Coaching Behavior Scale. We used four instruments with a total of 39 items to collect data.

Sociodemographic information form: It is developed by researchers, and consists of 8 items about nurses' personal and professional characteristics.

Motivation Scale (MS): The Motivation Scale (MS) was developed by Dündar, Özutku, and Taşpınar (2007) based on the study by Mottaz (1985). The MS consists of 24 items, 9 of which measure intrinsic motivation. It is a 5-point Likert scale: 1 strongly disagree, 2 disagree, 3 neutral, 4 agree, 5 strongly agree.

The Dutch Work Addiction Scale (DUWAS): The DUWAS is a 14-item two-factor scale developed by Schaufeli, Taris, and Bakker (2006) to measure work addiction. Doğan and Tel (Jacobs, 2018). adapted the scale into Turkish. The scale includes two subscales, "working excessively" consisting of 9 items (e.g., "I spend more time working than on other activities", and "I feel in a hurry and racing against the clock"), and "working compulsively" consisting of 4 items (e. g., "I feel that there is something inside me that drives me to work hard"). The Turkish version of the DUWAS is scored on a 5-point Likert scale (1 never, 2 rarely, 3 sometimes, 4 often, 5 always).

Coaching Behavior: To measure coaching behavior, we used Coaching Behavior Scale (CBS) which is an 8-item one-dimension scale developed by Ellinger, Ellinger, and Keller (2003) and adapted into Turkish by Kalkavan (2014). The Turkish version of the CBS is scored on a 5-point Likert scale (1 strongly disagree, 2 disagree, 3 neutral, 4 agree, 5 strongly agree).

\section{Data Analysis}

The data were analyzed using SPSS version 20. Non-normally distributed variables were presented as median (minimum and maximum). When comparing the mean scale scores of the nurses according to their personal and professional characteristics, we used Mann-Whitney U-test to compare two groups, and the Kruskal-Wallis test to compare more than two groups. The level of statistical significance was determined as $\mathrm{p}<0.05$. We used Sobel test to investigate the mediating role among the variables. Sobel (1982) tests the significance of the indirect effect of an independent variable to a dependent variable through a mediator variable. Sobel's mediation model can be used to test complex models (Baron \& Kenny, 1986).

\section{Ethical Aspect of the Study}

Approval for the study was obtained from Lokman Hekim University Non-Interventional Clinical Research Ethics Committee (Decision number 2019/25 and Code no: 2019014). Written permission was obtained from the hospital administrations where the study was conducted. The nurses invited to the study were informed about the study, and those who gave consent that they were volunteers were included in the study. Nurses' credentials were not written on the data collection forms. 


\section{RESULTS}

Table 1 presents the number and percent distribution of nurses by sociodemographic characteristics.

Table 1. Number and percent distribution of nurses by sociodemographic characteristics

\begin{tabular}{|c|c|c|}
\hline Variables & Number (n) & Percent $(\%)$ \\
\hline \multicolumn{3}{|l|}{ Gender } \\
\hline Female & 232 & 86,25 \\
\hline Male & 37 & 13,75 \\
\hline \multicolumn{3}{|l|}{ Marital Status } \\
\hline Married & 173 & 64,31 \\
\hline Single & 96 & 35,69 \\
\hline Age & \multicolumn{2}{|c|}{$34,96 \pm 8,37$} \\
\hline \multicolumn{3}{|l|}{ Education Level } \\
\hline Vocational High School (VHS) & 47 & 17,47 \\
\hline Associate Degree & 44 & 16,36 \\
\hline University & 164 & 60,97 \\
\hline Master Degree & 14 & 5,20 \\
\hline \multicolumn{3}{|l|}{ Monthly Income (TRY) } \\
\hline $1000-2000$ & 20 & 7,43 \\
\hline 2001-3000 & 32 & 11,90 \\
\hline $3001-4000$ & 129 & 47,96 \\
\hline $4001-5000$ & 77 & 28,62 \\
\hline 5001 and higher & 11 & 4,09 \\
\hline \multicolumn{3}{|l|}{ Units } \\
\hline Emergency department & 26 & 9,67 \\
\hline Operating room & 36 & 13,38 \\
\hline Surgical unit & 33 & 12,27 \\
\hline Medical unit & 84 & 31,23 \\
\hline Outpatient clinic & 30 & 11,15 \\
\hline Intensive care unit & 60 & 22,30 \\
\hline \multicolumn{3}{|l|}{ Years of work experience } \\
\hline $1-5$ & 72 & 26,77 \\
\hline $6-10$ & 62 & 23,05 \\
\hline $11-15$ & 39 & 14,50 \\
\hline $16-20$ & 30 & 11,15 \\
\hline $20-25$ & 40 & 14,87 \\
\hline 26 years and longer & 26 & 9,67 \\
\hline
\end{tabular}

A total of 269 nurses participated in the study. Most of them were female $(86,25 \%)$. The mean age was $34,96 \pm 8,37$ years. More than half of the participants were married $(64,31 \%)$. Of the nurses, $60,97 \%$ graduated from university, $17,47 \%$ graduated from vocational high school, $16,36 \%$ had an associate's degree, and 5,20\% had a master's degree. The number distribution of the nurses by units were as follows; $26(11,11 \%)$ nurses were working at emergency department, $36(13,38 \%)$ at operating room, $33(31,23 \%)$ at surgical unit, $84(31,23 \%)$ at medical unit, $30(11,15 \%)$ at an outpatient clinic and $60(22,30 \%)$ at intensive care unit. Nurses who had 1$5(\mathrm{n}=72,26,77 \%)$ and $6-10(\mathrm{n}=62,23,05 \%)$ years of work experience constituted almost half of the participants

Table 2 presents the mean values, standard deviations, and Cronbach alpha coefficients for all measures. 
Table 2. Descriptive Statistics and Reliabilities ( $N=269)$

\begin{tabular}{lcccccc}
\hline & N & Mean & Min. & Max. & S.D. & Cron. Alpha- $\alpha$ \\
\hline The Dutch Work Addiction Scale (DUWAS) & 14 & 3,26 & 1,00 & 5,00 & 0,72 & 0,877 \\
Working excessively (WE) & 9 & 3,18 & 1,00 & 5,00 & 0,74 & 0,780 \\
Working compulsively (WC) & 4 & 3,37 & 1,00 & 5,00 & 0,80 & 0,789 \\
Coaching Behavior Scale (CBS) & 8 & 2,89 & 1,00 & 5,00 & 1,02 & 0,928 \\
Intrinsic Motivation Scale (IMS) & 9 & 3,86 & 1,00 & 5,00 & 0,78 & 0,852 \\
\hline
\end{tabular}

Table 2 shows Cronbach alpha coefficients for the scales. The DUWAS, the CBS, and the IMS showed good reliability with Cronbach's of $0,877,0,928$, and 0,852, respectively. Cronbach's alphas for the subscales WE and WC were 0,780 and 0,789, respectively, which showed that the subscales were fairly reliable.

The mean DUWAS total score of the nurses was $3,26 \pm 0,72$. The mean WE score was $3,18 \pm 0,74$, and the mean WC score was $3,37 \pm 0,80$. The mean CBS score was $2,89 \pm 1,02$, and the mean IMS score was $3,86 \pm 0,78$ for the participants. 
Table 3. Distribution of the mean scores for the scales by sociodemographic characteristics

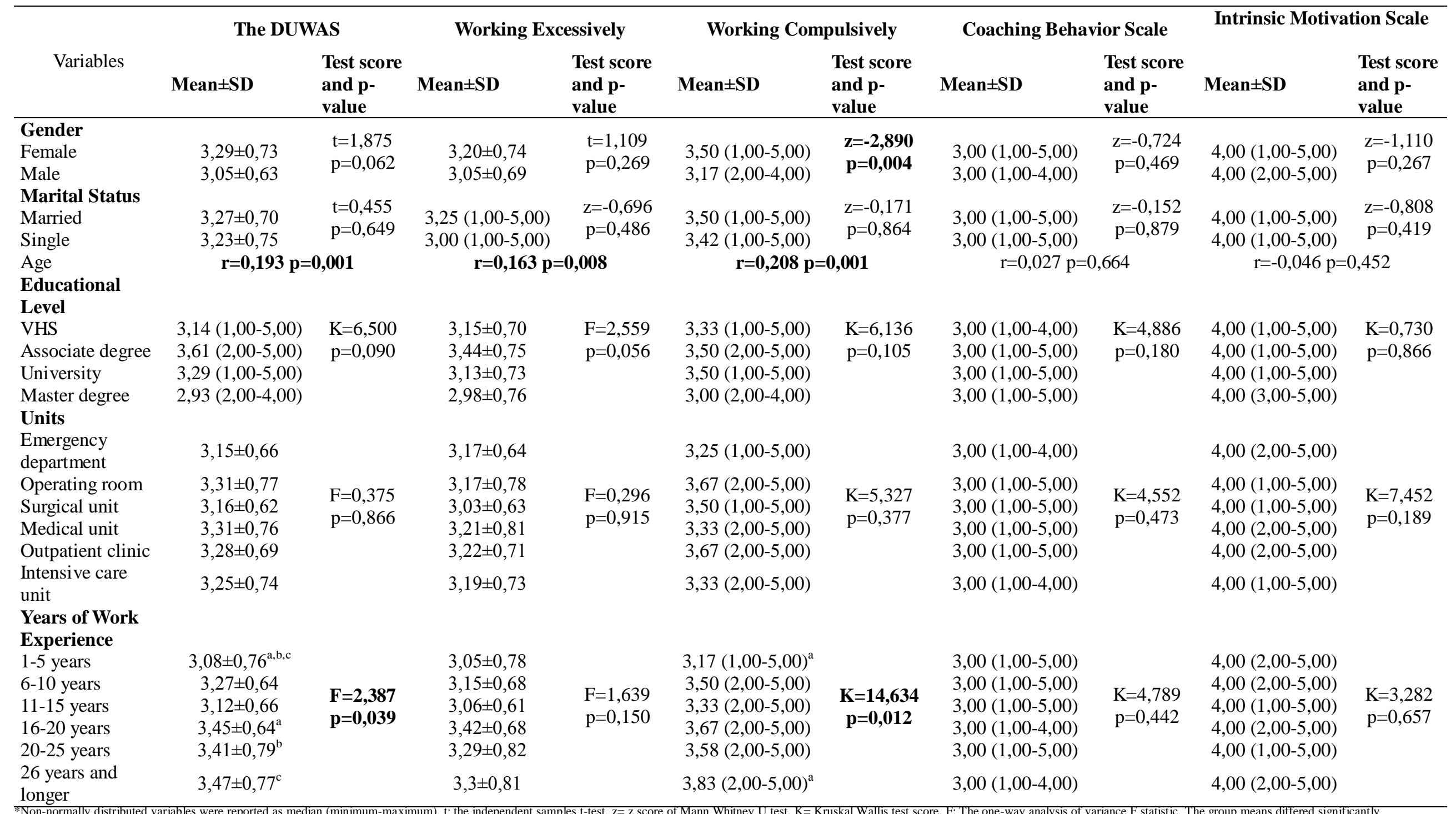

were shown by the same superscript letter. 
When analyzing the mean scores for the scales DUWAS, "coaching behavior" and "intrinsic motivation" and on the subscales "working excessively" and "working compulsively" according to sociodemographic characteristics, we found no difference in the mean total and subscale scores according to age group, gender, educational level and units $(p>0,05)$. However, there was a significant difference in the mean score of the subscale "working compulsively" according to gender $(p<0,05)$. The mean "working compulsively" score in the male sample was significantly lower than that in the female sample $(\mathrm{z}=-2,890 \mathrm{p}=0,004)$.

There was no linear correlation between age and the scores on "coaching behavior" and "intrinsic motivation" ( $p>0,05)$. On the other hand, age showed a weak positive linear correlation with the scores on the DUWAS, "working excessively" and "working compulsively" $\quad(r=0,193, \quad r=0,163, \quad r=0,208$, respectively, $\mathrm{p}<0,05)$. Although there was no difference in the mean DUWAS scores according to years of experience, the nurses with 1-5 years of experience had a lower mean DUWAS score $(3,08 \pm 0,76)$ than those with 16-20, 21-25, and 26 and above years of work experience $(\mathrm{F}=2,387 \mathrm{p}=0,039)$. Also, the "working compulsively" score of the nurses with $1-5$ years of experience $(3,17(1,00-5,00)$ was lower than that for those with 26 and above years of work experience $(3,83(2,00-5,00) \quad(\mathrm{K}=14,634$ $\mathrm{p}=0,012)$; however, no difference was found in the mean "working compulsively" scores according to years of experience.

Table 4. Correlation among the scales

\begin{tabular}{lccccc}
\hline The Scales & DUWAS & $\begin{array}{l}\text { Working } \\
\text { Excessively } \\
\text { (WE) }\end{array}$ & $\begin{array}{l}\text { Working } \\
\text { Compulsively } \\
\text { (WC) }\end{array}$ & $\begin{array}{l}\text { Coaching } \\
\text { Behavior } \\
\text { (CBS) }\end{array}$ & $\begin{array}{l}\text { Intrinsic } \\
\text { Motivation } \\
\text { (IMS) }\end{array}$ \\
\hline DUWAS & 1,000 & & & & \\
Working Excessively (WE) & $\mathbf{0 , 9 5 5}$ & 1,000 & & & \\
Working Compulsively (WC) & $\mathbf{0 , 9 3 2}$ & $\mathbf{0 , 7 8 2}$ & 1,000 & & \\
Coaching Behavior (CBS) & $\mathbf{0 , 2 4 3}$ & $\mathbf{0 , 2 5 5}$ & $\mathbf{0 , 1 9 8}$ & 1,000 & 1,000 \\
Intrinsic Motivation (IMS) & $\mathbf{0 , 1 4 8}$ & 0,115 & $\mathbf{0 , 1 7 0}$ & $\mathbf{0 , 1 4 0}$ & \\
p-values $<0,05$ are shown in bold. & & & & &
\end{tabular}

As presented in Table 4, the DUWAS had a weak positive linear correlation with the CBS and the IMS $(r=0,243, r=0,148$, respectively, $p<0,05)$. There was a weak positive linear correlation between the subscale $\mathrm{WE}$ and the CBS $(\mathrm{r}=0,255 \mathrm{p}<0,05)$. In addition, the subscale WC had a weak positive linear correlation with the CBS and the IMS ( $r=0,198, r=0,170$, respectively, $\mathrm{p}<0,05)$. And lastly, there was a weak positive linear correlation between the CBS and the IMS $(r=0,140 \mathrm{p}<0,05)$.

Table 5. Prediction of the dependent variable DUWAS from the CBS and the IMS

\begin{tabular}{llllllll}
\hline Variables & $\mathrm{B}$ & Std. Error & $\beta$ & $\mathrm{t}$ & $\mathrm{p}$ & Tolerance & VIF \\
\hline Intrinsic motivation & 0,107 & 0,055 & 0,116 & 1,944 & 0,053 & 0,980 & 1,020 \\
Coaching behavior & 0,161 & 0,042 & 0,227 & 3,799 & $<0,001$ & 0,980 & 1,020 \\
& $\mathrm{R} 2=0,072$ & $\begin{array}{l}\text { Adj. } \\
\mathrm{R} 2=0,065\end{array}$ & $\mathrm{~F}=10,345$ & $\mathrm{p}<0,001$ & Durbin Watson=2,007 & \\
\hline
\end{tabular}

Table 5 demonstrates regression analysis predicting the dependent variable DUWAS from the independent variables "coaching behavior" and "intrinsic motivation". 


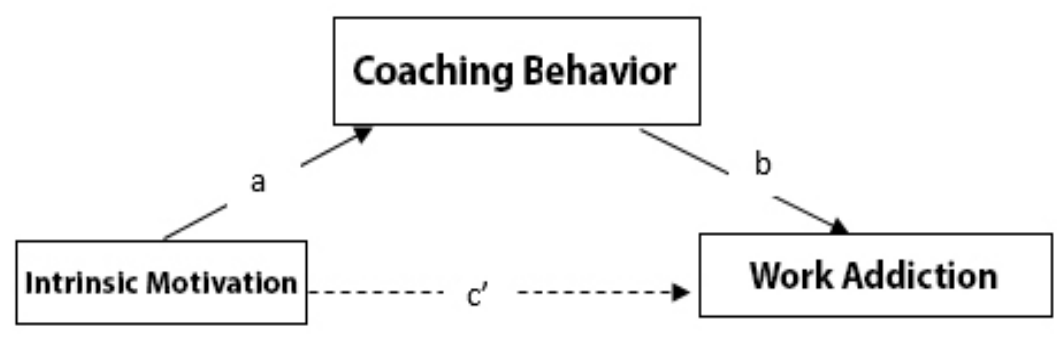

Figure 1. The Study Model

Figure 1 demonstrates the relationship between intstric motivation, coaching behaviour, work addiction.

We found that the CBS and the IMS explained $6,50 \%$ of the variability in the DUWAS, and the model was significant $(\mathrm{F}=10,345, \mathrm{p}<0,001)$.

Table 6. The mediating role of coaching behavior in the effects of intrinsic motivation on work addiction

\begin{tabular}{|c|c|c|c|c|c|c|c|c|}
\hline Steps & $\begin{array}{l}\text { Independent } \\
\text { Variables }\end{array}$ & $\begin{array}{l}\text { Dependent } \\
\text { Variables }\end{array}$ & B & $\beta(\mathrm{p})$ & $\mathrm{t}$ & Adj. R2 & $\mathrm{F}$ & $\mathrm{p}$ \\
\hline Step 1 & $\begin{array}{l}\text { Intrinsic } \\
\text { Motivation }\end{array}$ & Work Addiction & 0,136 & $0,148(0,015)$ & 2,441 & 0,022 & 5,957 & 0,015 \\
\hline Step 2 & $\begin{array}{l}\text { Intrinsic } \\
\text { Motivation }\end{array}$ & $\begin{array}{l}\text { Coaching } \\
\text { Behavior }\end{array}$ & 0,182 & $0,140(0,021)$ & 2,315 & 0,019 & 5,36 & 0,021 \\
\hline \multirow[t]{2}{*}{ Step 3} & $\begin{array}{l}\text { Intrinsic } \\
\text { Motivation }\end{array}$ & Work Addiction & 0,107 & $0,116(0,053)$ & 1,943 & 0,072 & 10,346 & $<0,001$ \\
\hline & Coaching Behavior & Work Addiction & 0,161 & $0,227(<0,001)$ & 3,799 & & & \\
\hline
\end{tabular}

Table 6 shows the mediation effect of coaching behavior on the relationship between intrinsic motivation and work addiction. In the relationship between intrinsic motivation and work addiction, $\mathrm{B}$ value was lower at step $3(B=0,107)$ than that at step $1(\mathrm{~B}=0,136) . \quad \beta$ value was significant at step 1 $(\mathrm{p}=0,015)$; however, it was not significant at step 3 ( $\mathrm{p}=0,053)$. According to these results, coaching behavior was found to have a full mediation effect on the relationship between intrinsic motivation and work addiction. The full mediation effect of coaching behavior on the relationship between intrinsic motivation and work addiction was tested using the Sobel test. The result of the test indicated that coaching behavior was a full mediator in this model $(\mathrm{z}=1,72 \mathrm{p}=0,04)$.

\section{DISCUSSION}

This study investigated the mediating role of coaching behavior in the relationship between intrinsic motivation and work addiction among nurses. According to our results, the mean IMS score of the nurses was slightly higher than the middle level, $3,86 \pm 0,78$. Intrinsically motivated activities are performed willingly without enforcement or a reward. In other words, when people value an activity personally or consider it significant, their motivation for engaging in this activity is intrinsic (Ryan \& Deci, 2000). The profession of nursing involves emotional relationships, such as providing patient care by showing love and affection, by its nature. It is argued, accordingly, that if intrinsic motivation plays a crucial role in the decision of becoming a nurse and in the development of work commitment (Wang et al., 2019). In the results of our study, the nurses' scores on the DUWAS, and the subscales WE and WC were found higher than the middle level; 3,26 $\pm 0,72$, $3,18 \pm 0,74$, and $3,37 \pm 0,80$, respectively. Working conditions of the profession may require nurses to work both excessively and compulsively. Nurses have a heavy workload, and the conditions such as working in shifts, night shifts, disagreements with patients, patient relatives, colleagues, and other health care professionals, occupational diseases, the experience of excessive work-related stress dueted emergency harder for them. It has been reported that workaholic employees experience many damaging outcomes such as low job satisfaction, burnout, work overload, and high, levels of health complaints (van Beek et al., 2012). However, it has been suggested that coaching can reduce mega outcomes such as occupational diseases, burnout an,d work stress, and improve job satisfaction and organizational commitment (Demerouti \& Bakker, 2011).

In our study, the mean CBS score of the nurses was close to the middle level, $2,89 \pm 1,02$. One of the factors that are useful in improving the coping skills of health care professionals is coaching behavior. 
Coaching behavior is a useful strategy for it encourages employees to transform learning into action, and involves teams in the improvement of patient care, and develops the basis of effective leadership (Hugill et al., 2018). Mau et al. (2020) have revealed that coaching intervention increases caring behavior among nurses. And it is also observed that patient satisfaction is higher for patients receiving care from the nurse group who got coaching intervention. In our study, whereas there was no difference in the mean scores on the scales IMS, CBS and DUWAS according to sociodemographic characteristics of the nurses $(p>0,05)$, there was a significant difference in the mean DUWAS score according to years of work experience ( $\mathrm{F}=2,387$ $\mathrm{p}=0,039)$. The mean DUWAS score of the nurses with $1-5$ years of experience $(3,08 \pm 0,76)$ was lower than that of those with 15 and above years of experience. In compliance with our results, other studies have also reported that there is no difference in work addiction according to the sociodemographic characteristics of participants (Burke et al., 2006; Spence \& Robbins, 1992). According to the results of correlation among the scales, there was a weak, positive, linear relationship between the DUWAS and the CBS, and the IMS ( $\mathrm{r}=0,243, \mathrm{r}=0,148$, respectively, $\mathrm{p}<0,05)$. These results have led us to conclude that there is a positive relationship between "intrinsic motivation", which refers to eagerness, interest and job satisfaction, and "work addiction", which involves work overload and "coaching behavior". In contrast with our results, a study conducted with 544 nurses by Van Beek et al. (2011) have revealed a negative relationship between intrinsic motivation and work addiction and indicated that work addiction has a negative relationship with intrinsic motivation among nurses.

Besides, we found a weak, positive, linear relationship between the subscale WE and the CBS $(\mathrm{r}=0,255 \mathrm{p}<0,05)$, and a weak, positive, linear relationship between the subscale WE and the CBS, and the IMS $(r=0,198, r=0,170$, respectively, $p<0,05)$. There was a weak, positive, linear relationship between the CBS and the IMS likewise ( $r=0,140$ $\mathrm{p}<0,05)$. We suggest that coaching behavior may help health care professionals enhance their skills, improve their performances, and maximize their potential, who work in an industry that is becoming increasingly competitive and highly stressful. We found that the CBS and the IMS explained 6,50\% of the variability in the DUWAS, and the model was significant $(\mathrm{F}=10,345, \mathrm{p}<0,001)$.

The result of structural equation modeling we used has revealed that coaching behavior fully mediates the effect of intrinsic motivation on work addiction.

\section{Limitations}

The data are limited to the opinions of nurses working at the hospital in Ankara where the study was carried out.

\section{CONCLUSION AND RECOMMENDATIONS}

This study investigated the relationship between work addiction, intrinsic motivation, and coaching behavior. Nursing has a complex structure including a variety of cognitive processes and behavioral abilities to protect and improve the health of individuals, families, and communities. It is a well-known fact that because of the heavy workload due to having great responsibility for maintaining the continuity of health services, nurses work excessively. Providing health care requires full commitment and attention. Thus, it is significant to increase motivation among health care workers. In our study, we found a positive relationship between working excessively and coaching behavior as well as between coaching behavior and intrinsic motivation. Coaching behavior had a positive effect on employee attitude. This situation may be interpreted as coaching behavior play that $\mathrm{s}$ an effective role in achieving organizational success as well as in improving job satisfaction and motivation among employees. Therefore, enhancing the coaching skills of nurse managers may be useful in improving the quality of patient care and increasing patient satisfaction.
Acknowledgements We would like to thank all nurses for participating in this study. Conflict of Interest The authors declare no conflict of interest

Ethic Approval The study was approved by the Non-Invasive Research Ethics Committee of Lokman Hekim University (issue no:2019/06, code no:2019014). Participating nurses were informed about the study, and written informed consent was obtained.

Financial Disclosure The authors declared that this study has received no financial support.

Authorship Statement As the authors of this paper, we have declared that they all have made a substantial contribution to the information or material submitted for the publication and we have approved the final version of this manuscript.

Contribution of Authors: N.B. and I.S. conceived and designed the study. N.B. collected data. N.B and I.S. wrote/drafted/edited the manuscript and interpreted the results. All authors approved the content of this manuscript. 


\section{REFERENCES}

Abu Yahya, O., Ismaile, S., Allari, R. S., \& Hammoudi, B. M. (2019). Correlates of nurses' motivation and their demographic characteristics. Nursing forum,

Ali, P. A. (2008). Professional development and the role of mentorship. Nursing standard, 22(42).

Baron, R. M., \& Kenny, D. A. (1986). The moderator-mediator variable distinction in social psychological research: Conceptual, strategic, and statistical considerations. Journal of personality and social psychology, 51(6), 1173.

Bonebright, C. A. (2002). The relationship of workaholism with stress, burnout, and productivity [Dissertation Thesis, The University of Iowa]. USA.

Buchan, J. (2010). Reviewing the benefits of health workforce stability. Human resources for health, 8(1), 29.

Burke, R. J., Matthiesen, S. B., \& Pallesen, S. (2006). Personality correlates of workaholism. Personality and Individual differences, 40(6), 1223-1233.

Demerouti, E., \& Bakker, A. B. (2011). The job demands-resources model: Challenges for future research. SA Journal of Industrial Psychology, 37(2), 01-09.

Dundar, S., Ozutku, H., \& Taspinar, F. (2007). Icsel ve dissal motivasyon araclarinin isgorenlerin motivasyonu uzerindeki etkisi: Ampirik bir inceleme [The effects of intrinsic and extrinsic motivation tools on employees' motivations: An empirical investigation]. Ticaret ve Turizm Egitim Fakultesi Dergisi, 2, 105119.

Ellinger, A. D., Ellinger, A. E., \& Keller, S. B. (2003). Supervisory coaching behavior, employee satisfaction, and warehouse employee performance: A dyadic perspective in the distribution industry. Human resource development quarterly, 14(4), 435-458.

Hammoudi, B. M., Ismaile, S., \& Abu Yahya, O. (2018). Factors associated with medication administration errors and why nurses fail to report them. Scandinavian journal of caring sciences, 32(3), 1038-1046.

Homer, J. B. (1985). Worker burnout: A dynamic model with implications for prevention and control. System Dynamics Review, 1(1), 42-62.

Hugill, K., Sullivan, J., \& Ezpeleta, M. L. (2018). Team coaching and rounding as a framework to enhance organizational wellbeing, $\&$ team performance. Journal of Neonatal Nursing, 24(3), 148-153.

Jacobs, S. (2018). An analysis of the evolution of mentorship in nursing. International Journal of Mentoring and Coaching in Education.

Kalkavan, S. (2014). Farkl Örgütsel Kültürlerde Yönetici Koçluk Davranışının Çalışanların İş Tatmini, Örgütsel Bağlılık ve Örgütsel Performans Algllarına Etkisi [Doctoral Dissertation, İstanbul Aydın University, Social Science Institute]. İstanbul, Turkey.

Kanai, A., Wakabayashi, M., \& Fling, S. (1996). Workaholism among employees in Japanese corporations: An examination based on the Japanese version of the Workaholism Scales. Japanese Psychological Research, 38(4), 192-203.

Kubota, K., Shimazu, A., Kawakami, N., Takahashi, M., Nakata, A., \& Schaufeli, W. B. (2010). Association between workaholism and sleep problems among hospital nurses. Industrial Health, 1006240015-1006240015

Manzi, A., Hirschhorn, L. R., Sherr, K., Chirwa, C., Baynes, C., \& Awoonor-Williams, J. K. (2017). Mentorship and coaching to support strengthening healthcare systems: lessons learned across the five Population Health Implementation and Training partnership projects in sub-Saharan Africa. Bmc Health Services Research, $17(3), 831$.

Mau, A., Limbong, K., \& Yetti, K. (2020). The effect of coaching and mentoring towards nurse's caring and patient satisfaction. Enfermería Clínica, 30, 18-22.

Mottaz, C. J. (1985). The relative importance of intrinsic and extrinsic rewards as determinants of work satisfaction. The Sociological Quarterly, 26(3), 365-385.

Quinones, C., \& Griffiths, M. D. (2015). Addiction to work: A critical review of the workaholism construct and recommendations for assessment. Journal of Psychosocial Nursing and Mental Health Services, 53(10), 48-59.

Ryan, R. M., \& Deci, E. L. (2000). Intrinsic and extrinsic motivations: Classic definitions and new directions. Contemporary educational psychology, 25(1), 54-67.

Saracel, N., Taşseven, Ö., \& Ay, N. (2015). Örgütsel stresin iş motivasyonu üzerine etkisi: Banka çalışanları üzerine bir uygulama.

Schaufeli, W. B., Taris, T. W., \& Bakker, A. B. (2006). Dr. Jekyll or Mr. Hyde: On the diff erences between work engagement and workaholism. Research companion to working time and work addiction, 193-217.

Shimazu, A., Schaufeli, W. B., \& Taris, T. W. (2010). How does workaholism affect worker health and performance? The mediating role of coping. International journal of behavioral medicine, 17(2), 154-160.

Spence, J. T., \& Robbins, A. S. (1992). Workaholism: Definition, measurement, and preliminary results. Journal of personality assessment, 58(1), 160-178.

van Beek, I., Hu, Q., Schaufeli, W. B., Taris, T. W., \& Schreurs, B. H. (2012). For fun, love, or money: What drives workaholic, engaged, and burned- out employees at work? Applied Psychology, 61(1), 30-55.

Van den Broeck, A., Schreurs, B., De Witte, H., Vansteenkiste, M., Germeys, F., \& Schaufeli, W. (2011). Understanding workaholics' motivations: A self- determination perspective. Applied Psychology, 60(4), 600-621.

Wang, E., Hu, H., Mao, S., \& Liu, H. (2019). Intrinsic motivation and turnover intention among geriatric nurses employed in nursing homes: the roles of job burnout and pay satisfaction. Contemporary nurse, 55(2-3), 195-210. 